\title{
VONIS SANKSI PIDANA TAMBAHAN OLEH HAKIM BERUPA PENGEMBALIAN KERUGIAN KEUANGAN NEGARA OLEH TERPIDANA TINDAK PIDANA KORUPSI DI PENGADILAN NEGERI DENPASAR ${ }^{1}$
}

\author{
Oleh : \\ I Ketut Rai Setiabudhi (raisetiabudhi fhunud@yahoo.com) \\ I Gede Artha (gedeartha58@yahoo.com) ${ }^{2}$
}

\begin{abstract}
Corruption in Indonesia has been so severed and widespread in the community and very alarming, its development continues to increase from year to year, both in number of cases and the amount of state financial losses and in terms of quality. These criminal offenses commit more systematic and scope into all aspects of life, Starting from lower level of the dominant and state officials or law enforcement. Judge in imposing sanctions not only imprisonment and also fined an additional punishment, including the return of financial loss to the state by state corruption, as well as some Denpasar District Court and the Court of Criminal Acts of Corruption (TIPIKOR) Denpasar. Legal basis of corruption in the judicial process is used by judges Act NO: 31 Jo Act 1999 NO: 20 of 2001 on Eradication of Corruption.
\end{abstract}

Keywords: additional punishment, corruption, financial losses.

\footnotetext{
${ }^{1}$ Karya ilmiah ini merupakan hasil penelitian yang dibiayai dari dana Dipa BLU Program Studi Magister (S2) Ilmu Hukum PPS UNUD dengan SK Direktur Nomor 1432/UN.14.4/HK/2013, telah dipresentasikan dalam seminar/FGD di Program Magister (S2) Ilmu Hukum pada tanggal 11 Nopember 2013.

${ }^{2}$ Para penulis adalah Dosen pada Program Studi Magister (S2) Ilmu Hukum Program Pascasarjana UNUD dan Fakultas Hukum UNUD Denpasar-Bali.
} 


\section{PENDAHULUAN}

\section{Latar Belakang Masalah}

Memasuki abad ke 21, perhatian dan keprihatinan komunitas internasional terhadap masalah korupsi yang menimpa berbagai negara berkembang termasuk negara Indonesia sangat menguat. Dalam berbagai kongres internasional mengenai "The Prevention of Crime and the Treatment of Offenders" yang diprakarsai oleh Perserikatan Bangsa Bangsa (PBB) masalah korupsi dan penanggulangannya cukup intens dibicarakan dan mendapat perhatian yang serius dari para peserta. Hal ini terbukti dengan ditempatkannya masalah korupsi sebagai bagian dari agenda pembicaraan di dalam berbagai kongres, misalnya kongres PBB ke tahun 1980, di Caracas Venesuela, tindak pidana korupsi diklasifikasikan ke dalam tipe kejahatan yang sukar dijangkau oleh hukum (offences beyond the reach of the law). ${ }^{3}$ Sementara itu dalam Konfrensi Internasional Anti Korupsi ke 7 tahun 1995 di Beijing, mencatat

\footnotetext{
${ }^{3}$ Muladi dan Barda Nawawi Arief, Bunga Rampai Hukum Pidana, Alumni, Bandung, 1984, hal. 133.
}

tindak pidana korupsi sebagai bentuk kejahatan yang sulit pembuktiannya. Kesimpulan yang sama diungkapkan pula di dalam kongres PBB ke 9 di Kairo, yang menyatakan bahwa pola perkembangan tindak pidana korupsi semakin menyulitkan aparat penegak hukum untuk melakukan penanggulangan. Oleh karena itu kongres merekomendasikan kepada anggota PBB agar memberikan perhatian yang intensif guna menemukan langkah-langkah baru dalam memerangi korupsi di kalangan pejabat publik. ${ }^{4}$

Mengingat demikian serius dan besarnya perhatian masyarakat internasional terhadap masalah korupsi yang melanda berbagai negara berkembang, maka sidang umum PBB pada tanggal 16 Desember 1996, mengeluarkan sebuah resolusi tentang pemberantasan korupsi. Resolusi tersebut dituangkan ke dalam sebuah dokumen yaitu United Nations Declaration Against Corruption and

${ }^{4}$ The United Nations, The United Nations and Crime Prevention, New York, 1996, hal. 31-32, sebagaimana dikutip oleh H. Elwi Danil, Korupsi Konsep, Tindak Pidana dan Pemberantasannya, PT. Raja Grafindo Persada, Jakarta, hal.62. 
Brybery in Internasional

Commercial Transantion. ${ }^{5}$ Dalam deklarasi tersebut PBB meminta dan mendorong negara-negara anggota PBB untuk mengambil langkahlangkah penanggulangan baik secara individu atau melalui kerja sama internasional dan regional, berdasarkan konstitusi dan prinsipprinsip dalam sistem hukum masingmasing. Demi mencapai efektifitas penegakan hukum dalam penanggulangan korupsi, di dalam deklarasi itu juga dianjurkan agar negara-negara anggota dapat mengadopsi ketentuan-ketentuan hukum yang diperlukan sepanjang hal tersebut memang belum terdapat di dalam sistem hukum masingmasing. ${ }^{6}$

5 Badan Pengawas Keuangan dan Pembangunan (BPKP), Strategi Pemberantasan Korupsi Nasional, Pusat Pendidikan dan Latihan BPKP, Jakarta, 1989, hal, 417-418., sebagaimana dikutip oleh H. Elwi Danil, Korupsi Konsep, Tindak Pidana dan Pemberantasannya, PT. Raja Grafindo Persada, Jakarta, hal.63.

6 The United Nations, United Nations Declaration Against Corruption and Brybery in Internasional Commercial Transantion, 16 Desember 1996. Deklarasi PBB ini lebih lanjut dipublikasikan dalam sebuah Resolusi PBB, Nomor A/Res/51/59/ tanggal 28 Januari 1977. sebagaimana dikutip oleh H. Elwi Danil, Korupsi Konsep, Tindak Pidana dan Pemberantasannya, PT. Raja Grafindo Persada, Jakarta, hal.63.
Visi masyarakat internasional untuk saling bekerja dalam pemberantasan tindak pidana korupsi semakin jelas terlihat dan menguat yang ditandai dengan ditanda tanganinya "Declaration of 8th International Conference Against Corruption" pada tahun 1997 di Lima, Peru. Bagian penting yang patut dicatat dari deklarasi tersebut adalah adanya klausula yang meletakkan keharusan bagi setiap negara untuk meningkatkan efektivitas hukum yang berkaitan dengan korupsi semaksimal mungkin. Keharusan mana mesti dijaga agar tetap berada dalam koridor konstitusi masing-masing negara dan norma-norma hak asasi manusia yang bersifat universal.

Perhatian masyarakat internasional sebagaimana tertuang dalam dokumen-dokumen di atas, paling tidak telah meletakkan dasardasar yang kuat untuk menunjukkan arah bahwa korupsi di masa mendatang harus diberantas dan tidak bisa ditoleransi. Oleh karena itu penanggulangan dan pemberantasan 
korupsi haruslah merupakan usaha bersama antar bangsa.

Keprihatinan masyarakat internasional mencapai puncaknya dengan dideklarasikan United Declarations Convention Against Corruption (UNCAC) yang disahkan dalam Konferensi Diplomatik di Merida Mexico pada Desember 2003. Sidang Majelis Umum PBB dengan Resolusi Nomor : 57/169, telah mengadopsi draf Konvensi PBB sebagai dokumen yang sah dan siap untuk ditanda tangani oleh negara peserta konferensi diplomatik tersebut. Di dalam bagian pembukaan konvensi tersebut ditegaskan bahwa masyarakat internasional peserta konvensi prihatin atas keseriusan (kegawatan) masalah-masalah dan ancamanancaman yang ditimbulkan oleh korupsi terhadap stabilitas dan keamanan masyarakat, yang melemahkan lembaga-lembaga dan nilai-nilai demokrasi, nilai-nilai etika dan keadilan seta membahayakan pembangunan berkelanjutan dan supremasi hukum. Oleh karena itu, perlu diyakininya suatu pendekatan komprehensif dan multidisipliner untuk mencegah dan memerangi korupsi secara efektif. ${ }^{7}$

Di Indonesia, masalah korapsi telah sejak lama mewarnai berbagai aspek dalam kehidupan masyarakat. Selama beberapa dasawarsa fenomena ini telah menjadi persoalan nasional yang amat sangat sukar ditanggulangi. Bahkan secara sinis ada komentar di sebuah jurnal asing yang mengulas kondisi korupsi di Indonesia dengan mengatakan bahwa "corruption is way of life in Indonesia" yang berarti bahwa korupsi telah menjadi pandangan dan jalan kehidupan bangsa Indonesia. ${ }^{8}$ Penilaian seperti ini tentunya sangat menyakitkan rasa kebangsaan dan tidak dapat diterima begitu saja, namun demikian jauh sebelumnya Muhammad Hatta, salah seorang tokoh proklamator

${ }^{7}$ H. Elwil Danil, Korupsi, Konsep, Tindak Pidana dan Pemberantasannya, PT. Raja Grafindo Persada, Jakarta, hal. 64.

${ }^{8}$ Amin Rais, Pengantar dalam Edy Suandi Hamid dan Muhammad Sayuti (ed.) Menyikapi Korupsi, Kolusi dan Nepotisme di Indonesia, Aditya Media, Yogyakarta, 1999, hal. xi. 
kemerdekaan Indonesia pernah melontarkan penilaian yang sama, dengan mengatakan bahwa korupsi cenderung sudah membudaya, atau sudah menjadi bagian dari kebudayaan bangsa Indonesia. ${ }^{9}$

Apa yang dikhawatirkan oleh Bung Hatta pada sekitar akhir tahun 60-an itu, sampai dewasa ini telah semakin menjadi sebuah fakta yang amat sulit dibantah. Skala korupsi yang terjadi telah menjadi semakin "menggurita". Korupsi di Indonesia tidak saja telah membudaya namun juga telah melembaga. Perilaku menyimpang itu telah mengalami proses institusionalisasi, sehingga hampir-hampir tidak ada lembaga negara yang steril dari perilaku menyimpang tersebut. ${ }^{10}$

Transparency International dalam laporan hasil pengkajiannya yang dipublikasikan dan dikutip oleh berbagai media massa di Indonesia, memposisikan Indonesia sejak beberapa tahun yang lalu ke dalam deretan negara dengan

\footnotetext{
${ }^{9}$ Mubyarto, Ekonomi dan Keadilan Sosial, Aditya Media, Yogyakarta, 1995, hal. 86.

${ }^{10}$ H. Elwi Danil, Op. Cit., hal. 65.
}

tingkat korupsi paling buruk di dunia. Berdasarkan hasil survei lembaga ini pada tahun 1998, skor Indonesia adalah 2,0. Kondisi ini jauh lebih buruk dari pada skor tahun sebelumnya, yaitu 2,72 pada tahun 1997 dan 2,65 pada tahun 1996. (nilai 10 berarti sangat bersih dan nilai 0 berarti sangat korupsi). ${ }^{11}$

Sementara itu, Political and Economic Risk Consultancy Ltd. (PERC) sebuah perusahan konsultasi yang banyak mengkaji dan mengulas tingkat resiko ekonomi dan bisnis dari negara-negara di Asia, dalam studinya terhadap masalah korupsi, berkesimpulan dan menempatkan Indonesia pada posisi sebagai sebuah negara dengan kondisi korupsi yang sangat serius dan memprihatinkan. Berdasarkan hasil survei lembaga ini terhadap 12 negara Asia pada tahun 1997, Indonesia memiliki angka 8,67 (nilai 0 berarti sangat bersih dan nilai 10 berarti sangat korupsi). Dengan angka seperti itu, PERC

11 Transparency International, sebagaimana dikutip oleh H. Elwi Danil, Korupsi Konsep, Tindak Pidana dan Pemberantasannya, PT. Raja Grafindo Persada, Jakarta, hal. 66. 
berkesimpulan bahwa Indonesia adalah negara dengan tingkat korupsi paling buruk di Asia. ${ }^{12}$

Dalam indeks persepsi tentang korupsi (corruption perspection index atau CPI) yang diluncurkan oleh Transparency International secara serentak di seluruh dunia pada 17 Nopember 2009, Indonesia memiliki skor 2,8. Itu berarti Indonesia masih diposisikan sebagai negara yang rawan korupsi dan sekaligus menunjukkan bahwa usaha pemberantasan korupsi masih belum berhasil dilakukan oleh pemerintah. Sementara itu PERC kembali mengungkapkan hasil surveinya pada bulan Maret 2010, Indonesia diposisikan sebagai negara paling korup di Asia Pasific. ${ }^{13}$

Di Indonesia usaha untuk menanggulangi masalah korupsi melalui kebijakan perundangundangan dan penegakan hukum pidana telah lama dilakukan, akan tetapi ternyata korupsi tetap saja ada,

12 Ibid.

${ }^{13}$ H. Elwi Danil, Korupsi Konsep, Tindak Pidana dan Pemberantasannya, PT. Raja Grafindo Persada, Jakarta, hal. 67. tumbuh dan berkembang seirama dengan perkembangan masyarakat sehingga semakin sulit diberantas. Pengaturan tentang tindak pidana korupsi di dalam peraturan perundang-undangan sudah dimulai semenjak berlakunya KUHP, meskipun tidak secara eksplisit menggunakan terminologi korupsi dalam rumusan tindak pidana sebagaimana diatur dalam Pasal 209, 210, 418, 419 dan Pasal 420 KUHP, akan tetapi sesungguhnya mengandung hakikat tindak pidana korupsi.

Instrumen hukum pidana khusus yang dewasa ini digunakan sebagai sarana untuk menanggulangi masalah korupsi adalah UndangUndang Nomor 31 Tahun 1999 Tentang Pemberantasan Tindak Pidana Korupsi sebagaimana telah diubah dengan Undang-Undang Nomor 20 Tahun 2001. Untuk menindaklanjuti amanat undangundang tersebut, dibentuk dan diberlakukan pula Undang-Undang Nomor 30 Tahun 2002 Tentang Komisi Pemberantasan Tindak Pidana Korupsi dan Undang-Undang 
Nomor 46 Tentang Pengadilan

Tindak Pidana Korupsi. Sebagai suatu produk hukum berbagai undang-undang korupsi tersebut diharapkan raampu mengemban fungsi ganda yaitu sebagai sarana represif dan sekaligus berfungsi sebagai sarana daya penangkal preventif. Namun pada kenyataannya tindak pidana korupsi tidak berkurang tetapi malah sebaliknya bagaikan fenomena gunung es. Hampir setiap hari dapat dibaca melalui liputan media massa tentang terungkapnya beberapa kasus tindak pidana korupsi yang tergolong besar (grand corruption) karena besarnya jumlah kerugian keuangan negara yang ditimbulkan oleh modus operandi kasus-kasus tersebut.

Tindak Pidana Korupsi di Indonesia sudah begitu parah dan meluas dalam kehidupan masyarakat dan sangat memprihatinkan. Perkembanganya terus meningkat dari tahun ke tahun, baik dari jumlah kasus yang terjadi maupun dari jumlah kerugian keuangan negara serta dari modus operandi dan kualitas tindak pidana yang dilakukan semakin sistematis, serta lingkupnya memasuki seluruh aspek kehidupan. Tindak pidana korupsi terjadi pada lembaga-lembaga formal kenegaraan seperti eksekutif, yudikatif dan legislatif. Dengan kualitas dan kuantitas tindak pidana korupsi yang selalu meningkat dan tidak terkendali akan membawa bencana tidak saja terhadap kehidupan perekonomian nasional tetapi juga pada kehidupan berbangsa dan bernegara. Tindak pidana korupsi yang meluas dan terjadi secara sistemik juga merupakan pelanggaran terhadap hak-hak sosial dan hak-hak ekonomi masyarakat, dengan karena iru tindak pidana korupsi tidak lagi dapat digolongkan sebagai kejahatan biasa (konvensional), melainkan telah tergolong suatu kejahatan luar biasa (extra ordinary crimes) malah lagi mengarah pada kejahatan kemanusiaan berat (crimes against humanity), sehingga dalam pemberantasannyapun tidak dilakukan dengan cara-cara biasa, tetapi memerlukan cara-cara yang luar biasa (extra ordinary power). 
Salah satu kebijakan dalam upaya pemberantasan tindak pidana korupsi adalah melalui penerapan sanksi pidana secara komulatif. Dalam ketentuan pidana UndangUndang No. 39 Tahun 1999 tentang Pemberantasan Tindak Pidana Korupsi yang telah dirubah dan disempurnakan dengan UndangUndang No. 20 Tahun 2001 telah tersirat dan tersurat bahwa bagi pelaku korupsi bukan saja dapat dikenai sanksi atau penundaan menurut hukum pidana bahkan dapat pula dikenai sanksi hukum perdata dan sanksi hukum administrasi. Secara penjatuhan sanksi menurut hukum pidana bahkan hakim dapat menjatuhkan sanksi pidana pokok ganda sekaligus dan sanksi pidana tambahan.

Khusus sanksi pidana tambahan berupa pengembalian kerugian keuangan negara atau perekonomian negara oleh terpidana korupsi. Dengan maksud dan tujuan untuk memulihkan kerugian dialami negara yang sempat diambil oleh terpidana untuk kepentingannya sendiri atau menguntungkan orang lain atau pihak lain yang menerimanya dengan modus-modus secara melawan hukum, dengan dampak menyengsarakan rakyat banyak atau merugikan keuangan negara, perekonomian negara dan menghambat pembangunan nasional.

\section{Rumusan Masalah}

Adapun permasalahan yang akan diteliti serta dikaji dalam penelitian terumus seperti berikut :

1. Apa dasar pertimbangan hakim dalam menjatuhkan sanksi pidana tambahan berupa pengembalian kerugian negara bagi terpidana tindak pidana korupsi di Pengadilan Negeri Denpasar?

2. Faktor-faktor yang menjadi kendala atau hambatan bila hakim menjatuhkan sanksi pidana tambahan berupa pengembalian keuangan negara yang telah dikorup oleh terpidana korupsi di Pengadilan Negeri Denpasar.

Pendekatan dan konsep untuk menjawab permasalahan di atas adalah memakai jenis pendekatan 
kasus (case approach). Dengan mengkaji dan menganalisis putusan hakim tentang kasus-kasus tindak pidana korupsi khususnya vonis hakim dengan sanksi pidana tambahan berupa pengganti kerugian keuangan negara atau perekonomian negara oleh terpidana.

\section{METODE PENELITIAN}

\section{Jenis Penelitian}

Dalam penelitian umum empiris dapat dipakai berbagai jenis penelitian diantaranya penelitian berlakunya hukum dan penelitian yang bertujuan untuk mengidentifikasi hukum yang hidup. ${ }^{14}$ Penelitian hukum yuridis empiris terdiri dari 4 komponen yaitu : 1) penelitian terhadap identifikasi hukum (hukum tidak tertulis), 2) penelitian terhadap efektifitas hukum, 3) penelitian perbandingan hukum, dan penelitian sejarah hukum. ${ }^{15}$ Jenis penelitian yang digunakan adalah

14 Ade Saptomo, 2009, PokokPokok Metodelogi, Penelitian Hukum Empiris Murni, Sebuah Alternatif, Penerbit Universitas Trisakti, Jakarta, hal. 42.

${ }^{15}$ H. Zainuddin Ali, 2010, Metode Penelitian Hukum, Cetakan ke-2, Sinar Grafika, Jakarta, hal. 30-45. jenis penelitian hukum yuridis empiris yang khusus meneliti mengenai efektifitas hukum yang membahas mengenai bagaimana hukum beroperasi dalam masyarakat. ${ }^{16}$

\section{Sifat Penelitian}

Sifat penelitian dalam penelitian ini adalah deskriptif. Menurut Moh. Nazir penelitian deskriptif adalah penelitian yang mempelajari masalah-masalah dalam masyarakat, serta tata cara yang berlaku dalam masyarakat serta situasi-situasi tertentu, termasuk tentang hubungan kegiatan-kegiatan, sikap-sikap, pandangan-pandangan, serta proses-proses yang sedang berlangsung dan pengaruh dari satu fenomena. ${ }^{17}$ Penelitian deskriptif juga bertujuan untuk menentukan ada tidaknya pengaruh antara suatu gejala dengan gejala lain dalam masyarakat. ${ }^{18}$ Terkait dengan hal tersebut, penelitian ini bertujuan

\footnotetext{
${ }^{16}$ Ibid, hal. 31.

17 Soerjono dan H. Abdurrahman, 1999, Metode Penelitian Hukum, Cetakan Pertama, Rineka Cipta, Jakarta, hal. 21.

${ }^{18}$ Amiruddin dan H. Zainal Asikin, 2008, Pengantar Metode Penelitian Hukum, Ed. 1-4, PT. Raja Grafindo Persada, Jakarta, hal. 25 .
} 
untuk mengetahui penerapan ancaman saksi pidana tambahan guna pengembalian kerugian keuangan negara dalam tindak pidana korupsi serta kendala dalam penerapan sanksi pidana tambahan pengembalian kerugian keuangan negara dalam tindak pidana korupsi di Pengadilan Negeri Denpasar.

\section{Sumber Data}

Adapun sumber data yang digunakan untuk mendukung penelitian ini didapat dari dua sumber, yaitu :

a. Sumber Data Primer

Data primer merupakan data yang diperoleh langsung dari sumber pertama yakni perilaku warga masyarakat melalui penelitian. ${ }^{19}$ Dalam penelitian ini data primer diperoleh dari data yang diperoleh langsung dari sumber pertama di lapangan baik berupa data menyangkut putusan Pengadilan khususnya penerapan rencana sanksi pidana guna pengembalian kerugian negera dalam tindak pidana korupsi

\footnotetext{
19 Soerjono Soekanto, 1986, Pengantar Penelitian Hukum, Cetakan Ketiga, UI Press, Jakarta, hal. 12 (Selanjutnya disebut Soerjono Soekanto II).
}

dan data yang diperoleh dari hasil wawancara dari informan.

b. Sumber Data Sekunder

Data sekunder antara lain mencakup dokumen-dokumen resmi, buku-buku, hasil-hasil penelitian yang berwujud laporan, buku harian, dan seterusnya. $^{20}$ Bahan sekunder yang dipergunakan dalam penelitian ini disebutkan dalam sumber bacaan.

\section{Teknik Pengumpulan Data}

\section{a. Teknik Studi Dokumen}

Studi dokumen merupakan langkah awal dari setiap penelitian hukum (baik normatif maupun sosiologis), karena penelitian hukum selalu bertolak dari premis normatif. $^{21}$ Dalam hal ini dengan mengumpulkan data yang bersumber dari kepustakaan yang relevan dengan permasalahan penelitian, yaitu dengan cara membaca dan mencatat kembali data yang kemudian dikelompokkan secara sistematis.

\section{b. Teknik Wawancara}

Wawancara merupakan cara yang digunakan untuk memperoleh

\footnotetext{
${ }^{20}$ Ibid.

${ }^{21}$ Amiruddin dan H. Zainal Asikin,
} Op. Cit., hal. 68 . 
keterangan secara lisan guna mencapai tujuan tertentu. ${ }^{22}$ Dalam hal ini data diperoleh melalui proses interview atau wawancara kepada pihak-pihak yang terkait dengan permasalahan penelitian di lapangan yaitu wawancara kepada Hakim Pengadilan Negeri Denpasar khususnya yang pernah memeriksa, mengadili dan memutus perkara tindak pidana korupsi, untuk memperoleh informasi dan data yang pasti dan akurat.

\section{Teknik Penentuan Sampel Penelitian \\ Dalam kaitannya dengan} penentuan sampel, maka terdapat 2 (dua) cara atau teknik yang dapat dipergunakan yaitu teknik probability sampling dan teknik non probability sampling. Penelitian ini mempergunakan teknik non probability sampling, yaitu purposive sampling. Dimana penentuan sampel dilakukan berdasarkan tujuan tertentu, yaitu sampel dipilih atau ditentukan

${ }^{22}$ Burhan Ashshofa, 1998, Metode Penelitian Hukum, Cetakan Kedua, PT. Rineka Cipta, Jakarta, hal. 95. sendiri oleh si peneliti, yang mana penunjukan dan pemilihan sampel berdasarkan pertimbangan bahwa sampel telah memenuhi kriteria dan sifat-sifat atau karakteristik tertentu yang mempunyai ciri utama di populasinya. $^{23}$ Sampel yang dimaksud adalah beberapa hakim khususnya yang pernah memeriksa, mengadili dan memutus perkara korupsi di Pengadilan Negeri Denpasar, dengan menjatuhkan sanksi pidana tambahan kepada terpidana korupsi berupa pengembalian kerugian keuangan negara.

\section{Teknik Analisis Data}

Proses analisis data merupakan pekerjaan untuk menemukan tema-tema dan merumuskan hipotesa-hipotesa, meskipun sebenarnya tidak ada formula yang pasti untuk dapat digunakan untuk merumuskan hipotesa, hanya saja analisis data tema dan hipotesis tersebut lebih

23 Fakultas Hukum Universitas Udayana, 2009, Pedoman Pendidikan Fakultas Hukum Universitas Udayana, Denpasar-Bali, hal. 74-75. 
diperdalam dengan menggabungkannya dengan sumber-sumber data yang ada. ${ }^{24}$ Adapun keseluruhan data yang telah didapat akan dianalisis secara kualitatif atau lebih dikenal dengan istilah analisis deskriptif kualitatif. Dimana keseluruhan data yang terkumpul baik data primer maupun data sekunder akan diolah dan dianalisis secara sistematis yang dipaparkan dalam bentuk uraianuraian yang berhubungan dengan teori ataupun asas hukum yang terdapat dalam Hukum Pidana sehingga memperoleh suatu kesimpulan dan gambaran yang jelas dalam pembahasan masalah.

\section{HASIL DAN PEMBAHASAN}

1. Praktek Penerapan Penjatuhan Sanksi Pidana Tambahan Oleh Hakim Berupa Pengembalian Kerugian Keuangan Negara Dalam Kasus Tindak Pidana Korupsi

Pengadilan Negeri Denpasar membawahi pula kompetensi Pengadilan TIPIKOR Denpasar. Pengadilan TIPIKOR Denpasar baru

\footnotetext{
${ }^{24}$ Ibid, hal. 66.
}

berdiri tahun 2011. Sehingga peneliti melakukan penelitian terhadap kasus-kasus Tindak Pidana Korupsi dan mencari datanya baik di Pengadilan Negeri Denpasar mulai tahun 2012. Untuk menyesuaikan pencarian data di Pengadilan TIPIKOR Denpasar mulai tahun 2012, karena tahun 2011 Pengadilan TIPIKOR baru berdiri dan belum ada korupsi yang diperiksa, padahal wilayah hukum Pengadilan TIPIKOR meliputi seluruh kabupaten di Bali sebanyak 8 (delapan) kabupaten dan 1 (satu) kota.

Sejak tahun 2012-2013 Pengadilan Negeri Denpasar dan Pengadilan TIPIKOR Denpasar memeriksa dan memutus perkara Tindak Pidana Korupsi sebanyak 29 (dua puluh sembilan kasus). Dengan rincian kasus 21 (dua puluh satu) kasus diperiksa oleh Peradilan Umum Pengadilan Negeri Denpasar dengan sanksi berupa pidana penjara dan/atau sanksi pidana denda yang bervariatif. Atau Pengadilan Negeri Denpasar atau di Peradilan Umum tidak ada hakim atau putusan pengadilan dengan penjatuhan sanksi 
pidana tambahan berupa pengembalian kerugian keuangan negara.

Pemeriksaan perkara tindak pidana korupsi di Pengadilan TIPIKOR sejak efektif melaksanakan tugas dan fungsi peradilannya mulai tahun 2012 telah berhasil memeriksa dan memutus sebanyak 8 (delapan) kasus tindak pidana korupsi. Dari pemeriksaan kasus sebanyak 8 (delapan) kasus tersebut sanksi yang dijatuhkan dalam putusan (vonnis)nya berupa pidana penjara dan/atau denda serta sanksi pidana tambahan berupa pengembalian kerugian keuangan negara atau perekonomian negara. Kasus-kasus tindak pidana korupsi tersebut atas nama terdakwa :

1. Desak Putu Ari Padmini

2. I Nengah Arnawa, S.Sos., MM dan Cokorda Istri Trisnadewi, SE (dari PN Bangli)

3. Nyoman Pastika, SE

4. I Wayan Kari Bagus Pramanta

5. Dr. Drs. Putu Bagiada, MM (dari PN Singaraja)

6. I Wayan Sukaja, S.Sos (dari PN Tabanan)

7. I Dewa Gde Ramayana

8. Gede Budiasa
Dari jumlah 8 (delapan) terdakwa tindak pidana korupsi yang diperiksa dan diputus oleh Peradilan TIPIKOR Denpasar, rincian masingmasing pengembalian keuangan negara sebagai sanksi pidana tambahan oleh hakim atas putusannya terekapitulasi seperti uraian tabel berikut :

Tabel Data Kasus Terdakwa dan

Kerugian Keuangan Negara di Pengadilan TIPIKOR Denpasar

\begin{tabular}{|c|l|l|}
\hline No & \multicolumn{1}{|c|}{$\begin{array}{c}\text { Nama } \\
\text { Terdakwa }\end{array}$} & $\begin{array}{c}\text { Nilai Kerugian } \\
\text { Keuangan Negara } \\
\text { Yang } \\
\text { Dikembalikan }\end{array}$ \\
\hline 1 & $\begin{array}{l}\text { Desak Putu } \\
\text { Ari Padmini }\end{array}$ & Rp. 290.998.750 \\
\hline 2 & $\begin{array}{l}\text { I Nengah } \\
\text { Arnawa, } \\
\text { S.Sos, MM } \\
\text { dan Cokorda } \\
\text { Istri } \\
\text { Trisnadewi, } \\
\text { SE }\end{array}$ & Rp. 1.395 .000 .000 \\
\hline 3 & $\begin{array}{l}\text { Nyoman } \\
\text { Pastika, SE }\end{array}$ & Rp. \\
\hline 4 & $\begin{array}{l}\text { I Wayan Kari } \\
\text { Bagus } \\
\text { Pramanta }\end{array}$ & Rp. 625.670 .000 \\
\hline 5 & $\begin{array}{l}\text { Dr. Drs. Putu } \\
\text { Bagiada, MM }\end{array}$ & Rp. 574.709 .326 \\
\hline 6 & $\begin{array}{l}\text { I Wayan } \\
\text { Sukaja, S.Sos }\end{array}$ & Rp. 431.000 .000 \\
\hline 7 & $\begin{array}{l}\text { I Dewa Gde } \\
\text { Ramayana }\end{array}$ & Rp. 62.745 .000 \\
\hline
\end{tabular}




\begin{tabular}{|l|l|l|}
\hline 8 & Gede Budiasa & Rp.1.863.126.650 \\
\hline \multicolumn{2}{|c|}{ Jumlah } & Rp. 4.644.249.726 \\
\hline \multicolumn{2}{|c|}{$\begin{array}{l}\text { Empat milyar enam ratus empat puluh } \\
\text { empat juta dua ratus empat puluh } \\
\text { sembilan ribu tujuh ratus dua puluh } \\
\text { enam rupiah }\end{array}$} \\
\hline
\end{tabular}

Dari 8 (delapan) kasus

Tindak Pidana Korupsi yang diperiksa dan diputus oleh Peradilan TIPIKOR dari hampir seluruh Pengadilan Negeri di Bali, uang negara yang dapat terselamatkan sejumlah Rp. 4,5 milyar lebih. Pengadilan Negeri Denpasar dalam 2 (dua) tahun terakhir mulai tahun 2012 hingga Oktober 2013 memeriksa dan memutus kasus Tindak Pidana Korupsi sebanyak 21 (dua puluh satu) kasus. Sanksi pidana yang dijatuhkan berupa pidana penjara sebanyak 19 orang terdakwa rata-rata 1 (satu) tahun ditambah pidana denda bervariasi antara Rp. 20 juta - Rp. 300.000.000 (Tiga ratus juta rupiah). Namun yang umum dijatuhkan pidana denda antara Rp. 20 juta - Rp. 50 juta. Beda halnya di Pengadilan TIPIKOR denda yang dijatuhkan antara Rp. 100 juta - Rp. 300 juta. Bila terpidana tidak membayar denda atau sanksi pidana tambahan berupa pengembalian kerugian keuangan negara atau perekonomian negara maka diganti dengan pidana kurungan sebagai pengganti denda selama 2 (dua) bulan. Namun pidana tambahan pengganti denda kerugian keuangan negara bila tidak dibayar, maka aset kepemilikan terdakwa akan dilelang oleh negara untuk pengembaliannya. Apabila terpidana tidak memiliki aset untuk dilelang, maka terakhir terpidana diwajibkan menjalani pidana kurungan sebagai pengganti kewajiban yang mereka tidak dapat memenuhi perintah putusan (vonis) tambahan tersebut. Pidana kurungan pengganti ini berkisar lamanya antara 6 (enam) bulan hingga 1 (satu) tahun kurungan.

\section{Faktor-Faktor Hambatan Sebagai Kendala Dalam Pengembalian Aset Negara Oleh Terpidana Tindak Pidana Korupsi yang Dijatuhi Sanksi Pidana Tambahan Berupa Pengembalian Kerugian Negara atau Perekonomian Negara}

Dari para informan hakim terdiri dari 6 (enam) orang yang diwawancarai pada prinsipnya 
berpendapat senada bahwa faktorfaktor hambatan sebagai kendala sulitnya para terpidana dalam mengembalikan aset negara yang sempat diambil (dikorup) olehnya, sebagai wujud sanksi pidana tambahan berupa pengembalian kerugian negara tersebut disebabkan beberapa kendala seperti diantaranya menyangkut hal-hal :

1. Aset negara yang sempat dikorup telah habis dipakai / dinikmati oleh terpidana beserta keluarganya.

2. Aset negara telah beralih pada orang lain atau pihak lain yang sulit dilacak.

3. Aset negara telah dikaburkan melalui cara-cara pencucian uang (money laundering).

4. Aset negara ada yang disumbangkan pada masyarakat yang tidak jelas peruntukannya dengan dalih guna kepentingan sosial.

5. Aset negara yang kepemilikannya atas nama pihak lain (seperti keluarga, kroni terpidana, apalagi pihak-pihak lain yang tidak jelas orangnya) sulit untuk disita atau dilelang oleh negara, karena memerlukan proses gugatan hukum perdata.

6. Terpidana telah meninggal dunia.

7. Ahli waris terpidana tidak mau bertanggung jawab.

8. Aset yang dikuasai keluarga terpidana tidak mencukupi guna pengembalian kerugian keuangan negara yang sempat dikorup oleh terpidana.

9. Terpidana atau keluarga dan ahli waris terpidana sama sekali tidak memiliki aset yang bisa dilelang untuk memenuhi jumlah uang / nilai materiil sebagai pidana tambahan pengganti kerugian keuangan negara sesuai jumlah yang diputuskan oleh hakim.

10. Aset negara yang dikorup terpidana berada di luar negeri (tersimpan pada suatu bank asing) yang sulit untuk dilacak dan ditembus.

Demikian berbagai faktorfaktor sebagai kendala dan hambatan dalam usaha pengembalian aset negara yang dikorup oleh terpidana korupsi dengan sanksi pidana tambahan pengganti guna 
pengembalian kerugian negara atau perekonomian negara yang sulit untuk direalisasikan oleh penegak hukum atau pemerintah.

\section{SIMPULAN DAN SARAN}

\section{Simpulan}

Dari penelitian yang dilakukan terhadap "Vonis Sanksi Pidana Tambahan Oleh Hakim Berupa Pengembalian Kerugian Keuangan Negara Oleh Terpidana Tindak Pidana Korupsi Di Pengadilan Negeri Denpasar", dapat disimpulkan hal-hal seperti berikut :

1. Bahwa putusan pengadilan atau vonis hakim di Pengadilan Negeri Denpasar menyangkut penjatuhan sanksi pidana tambahan berupa pengembalian kerugian keuangan negara belum semua terdakwa korupsi disertai dengan putusan pidana tambahan. Putusan Pengadilan Negeri Denpasar dalam peradilan umum hanya menjatuhkan sanksi jenis pidana (straaf sort) berupa pidana pokok seperti pidana penjara dan pidana denda terhadap terdakwanya. Kalau
Peradilan khusus yakni Pengadilan Tindak Pidana Korupsi (TIPIKOR) Denpasar yang wilayah hukumnya meliputi 8 (delapan) kabupaten dan 1 (satu) kota di Bali telah menjatuhkan sanksi dalam putusan (vonisnya) dengan sanksi pidana tambahan berupa pengembalian kerugian keuangan negara oleh terdakwa kepada negara. Jumlah kerugian yang diwajibkan untuk dikembalikan disesuaikan dengan jumlah kerugian negara yang timbul sesuai nilai yang telah diambil atau dikorupsi oleh terdakwa seperti tuntutan oleh Jaksa Penuntut Umum. Disamping hakim membebani terdakwa dengan sanksi pidana tambahan, juga dijatuhi pidana pokok berupa pidana penjara dan/atau pidana denda, serta bila terdakwa tidak bisa membayar denda akan diganti dengan pidana kurungan sebagai pengganti denda. Begitu pula apabila terpidana korupsi tidak membayar sanksi pidana tambahan, maka aset yang 
dimiliki terpidana atau ahli

warisnya dilelang guna menutupi

kerugian negara yang diakibatkan

timbul dari tindak pidana korupsi

yang sempat terdakwa perbuat.

2. Faktor-faktor kendala sebagai penghambat kembalinya aset negara, walaupun vonis hakim telah menjatuhkan sanksi pidana tambahan berupa pengembalian kerugian keuangan negara oleh terpidana korupsi, meliputi halhal seperti adanya : terpidana melarikan diri, terpidana meninggal dunia, terpidana telah jatuh failit atau jatuh miskin, aset terpidana telah dicuci (aset telah dialihkan/money laundering), aset terpidana telah habis dipakai keperluan pribadi atau norma lain, aset terpidana berada pada bank yang telah jatuh pailit, aset terpidana tidak mencukupi guna pengembalian kerugian keuangan negara, keluarga tidak mau bertanggung jawab untuk ikut menanggung beban terpidana tidak memiliki keluarga lagi.

\section{Saran}

a. Agar kedepan setiap kasus tindak pidana korupsi yang menimbulkan kerugian keuangan negara atau perekonomian negara. Hakim dalam putusannya untuk selalu menjatuhkan sanksi dengan pidana tambahan berupa pengembalian keuangan negara tersebut, agar negara tidak dirugikan dan guna untuk kepentingan pembangunan bangsa yang dapat dinikmati oleh masyarakat luas.

b. Agar kedepan hakim dalam memutus perkara tindak pidana korupsi khsusnya peradilan di Peradilan Umum/Pengadilan Negeri bukan saja memutus dengan pidana pokok berupa pidana penjara dan pidana denda saja, juga mesti disertasi dengan vonis pidana tambahan berupa pengembalian kerugian keuangan 
negara/perekonomian

negara, selama ini baru beberapa saja putusan Pengadilan Negeri yang menyertai putusannya dengan sanksi pidana tambahan. Selebihnya sanksi pidana tambahan berupa pengembalian kerugian keuangan negara hanya dijatuhkan oleh Pengadilan TIPIKOR.

\section{DAFTAR PUSTAKA}

Ade Saptomo, 2009, Pokok-Pokok Metodelogi, Penelitian Hukum Empiris Murni, Sebuah Alternatif, Penerbit Universitas Trisakti, Jakarta.

Amin Rais, Pengantar dalam Edy Suandi Hamid dan Muhammad Sayuti (ed.), 1999, Menyikapi Korupsi, Kolusi dan Nepotisme di Indonesia, Aditya Media, Yogyakarta.

Amiruddin dan H. Zainal Asikin, 2008, Pengantar Metode Penelitian Hukum, Ed. 1-4, PT. Raja Grafindo Persada, Jakarta.

Burhan Ashshofa, 1998, Metode Penelitian Hukum, Cetakan
Kedua, PT. Rineka Cipta, Jakarta.

Mubyarto,1995, Ekonomi dan Keadilan Sosial, Aditya Media, Yogyakarta.

Muladi dan Barda Nawawi Arief, 1984, Bunga Rampai Hukum Pidana, Alumni, Bandung.

H. Elwi Danil, Korupsi Konsep, Tindak Pidana dan Pemberantasannya, PT. Raja Grafindo Persada, Jakarta.

H. Zainuddin Ali, 2010, Metode Penelitian Hukum, Cetakan ke-2, Sinar Grafika, Jakarta.

Soerjono dan H. Abdurrahman, 1999, Metode Penelitian Hukum, Cetakan Pertama, Rineka Cipta, Jakarta.

Soerjono Soekanto, 1986, Pengantar Penelitian Hukum, Cetakan Ketiga, UI Press, Jakarta.

Fakultas Hukum Universitas Udayana, 2009, Pedoman Pendidikan Fakultas Hukum Universitas Udayana, Denpasar-Bali. 
Undang-Undang

The United Nations, The United Nations and Crime Prevention, New York, 1996, hal. 31-32, sebagaimana dikutip oleh H. Elwi Danil, Korupsi Konsep, Tindak Pidana dan Pemberantasannya, PT. Raja Grafindo Persada, Jakarta.

Badan Pengawas Keuangan dan Pembangunan (BPKP), Strategi Pemberantasan Korupsi Nasional, Pusat Pendidikan dan Latihan BPKP, Jakarta, 1989, hal, 417-418., sebagaimana dikutip oleh H. Elwi Danil, Korupsi Konsep, Tindak Pidana dan Pemberantasannya, PT. Raja Grafindo Persada, Jakarta.

The United Nations, United Nations Declaration Against Corruption and Brybery in Internasional Commercial Transantion, 16 Desember 1996. Deklarasi PBB ini lebih lanjut dipublikasikan dalam sebuah Resolusi PBB, Nomor A/Res/51/59/ tanggal 28 Januari 1977. sebagaimana dikutip oleh H. Elwi Danil,
Korupsi Konsep, Tindak Pidana dan Pemberantasannya, PT. Raja Grafindo Persada, Jakarta.

Transparency International, sebagaimana dikutip oleh $\mathrm{H}$. Elwi Danil, Korupsi Konsep, Tindak Pidana dan Pemberantasannya, PT. Raja Grafindo Persada, Jakarta.

Undang-Undang Nomor : 31 Tahun 1999 Tentang Pemberantasan Tindak Pidana Korupsi sebagaimana telah dirubah dengan Undang-Undang Nomor : 20 Tahun 2001 Tentang Pemberantasan Tindak Pidana Korupsi.

Undang-Undang Nomor : 30 Tahun 2002 Tentang Komisi Pemberantasan Tindak Pidana Korupsi (KPK).

Undang-Undang Nomor : 46 Tahun 2009 Tentang Peradilan Tindak Pidana Korupsi (TIPIKOR). 